\title{
The Population Growth and Carrying Capacity in Semarang City
}

\author{
Hariyanto $^{1, *}$, Sudharto P Hadi ${ }^{1}$, and Imam Buchori ${ }^{2}$ \\ ${ }^{1}$ Doctoral Program at Environment Science of Post Graduate School Diponegoro University Indonesia \\ ${ }^{2}$ Department of Urban Plannung, Engineering Faculty Diponegoro University Indonesia
}

\begin{abstract}
Population growth and development of city activities take some lands to carry them. As a result, land use competition happens among persons, society or sector. Land necessity for settlement, industry, or sector has taken over farm land, therefore farm land has been converted intensively and massively. Chronologically, population growth will cause land necessity increase. Unproductive land, especially farm land will be converted. Furthermore, farm land conversion will cause carrying capacity change. Carrying capacity has certain bio capacity. With the population growth, it will increase resource consumption; on the other side, farm land conversion will decrease carrying capacity. The objective of the study is to know about the influence of population growth towards carrying capacity (bio capacity) in Semarang city. Land consumption per capita is indeed influenced by city population, the higher the population is, the lower the land consumption per capita. With the population growth, it will influence carrying capacity. Carrying capacity here is the ratio of area to population. Analytical descriptive method is applied in the study with all sub-districts in Semarang city as the analys is unit. Population here is sub-district area and population per sub-district in Semarang city. Population growth data period is from 2000 until 2015. Main variables of the study are area per sub-district, population, population growth, carrying capacity. Result of the study shows significant influence of carrying capacity decrease, especially some outskirts in Semarang city. This condition happens because the outskirts in Semarang city tend to have dense population growth. Range of carrying capacity in Semarang city is from 0,007 to 0,117 of 0 to 1 . Almost all sub-districts in Semarang city show miserable condition, except Mijen and Tugu. The conclusion of the study is that population will decrease carrying capacity. Therefore, the government should control population growth by paying attention to its distribution.
\end{abstract}

\section{Background of the study}

Land is a kind of important natural recourse for human life as it is needed in every human activity such as agriculture, industry, settlement, and so on. In other word, it is said that land has direct and indirect multiple purpose use. Land is useful to fulfil material need, health, psychological need, and it is also important to protect other natural resources like vegetation and water [1]. Land supply which is relatively constant will make it as a scare commodity, whereas population in Indonesia is growing.

Based on census in 2010, population in Indonesia was 237,556,363, and it became 245,862,034 in 2014 with 58 percent population distribution that was still concentrated in Java Island, followed by 21 percent in Sumatera Island. The growing population mostly happens in some big cities such as Jakarta, Surabaya, Semarang, etc. Semarang has an average population growth of 2.04 percent per year. Data from BPS shows that population in Semarang city has reached 1,763,370 (2015). It is bigger than population in 2001 that was $1,350,005$.
In order to fulfil some needs of the growing population, land demand is also increased for many kinds of activities. This case has changed the function of the land (land conversion) that gives some disadvantages for environment conservation.

The function change often happens to the land which has important function for human life, like fertile farm land that is changed into settlement, infrastructure, and so on. The function change of farm land has changed rapidly and massively.

Kusumawati stated that industrial sector takes over agriculture sector, the higher the function change of farm land, the higher the miserable land will be [2]. Settlement that is extended to some rural areas causes the fertile farm land does not produce any more food material to fulfil people's need. This condition shows that farm land will keep on decreasing due to population problems and growing development in Indonesia. But unfortunately, the decrease of farm land is not followed by extensive farm (creating rice field out of Java island), therefore growing population affects the decrease of land capacity.

Farm land conversion is not merely caused by growing population, but also caused by growing

*orresponding author: hariyantogeo@yahoo.com 
economy of an area in form of growing urban sprawl. The growing urban sprawl can be infrastructure, settlement, industry, activity centre, etc. that will converse the farm land. The phenomena of farm land conversion are absolute impact for an urban growth [3].

\section{Related literatures}

Regulation of Indonesia Republic No.41 year 2009 about Sustainable Protection for Food Farm Land indicates that the growing population and economy and also industry will cause degradation, function change, and fragmentation for farm land. This phenomenon threaten nationally to have self-sufficiency in food. Through this case the government of Indonesia cannot deny that growing population can threaten farm land, or even worse than that, it can threaten self-sufficiency in food. The government of Indonesia used to appeal selfsufficiency in food, but actually Indonesia has imported some food materials instead [4].

\section{Land capacity}

Land capacity is carrying capacity to support life of the human beings and other living things that live around. It is measured by land demand which means maximum population that can be carried by available natural resources stated by absolute number in form of $\alpha$ [4].

\section{Method of the analysis}

Land capacity is calculated based on Regulation of Environment Minister Number 17 year 2009 about Guidance of Carrying Capacity Determination in an Area (Region) Spatial Planning. According to the regulation, in order to get to know land capacity of an area (region), the following steps should be conducted:

1. Land supply calculation with the following formula:

$$
\mathrm{SL}=\frac{\Sigma(\mathrm{Pi} \times \mathrm{Hi})}{\mathrm{Hb}} \times \frac{1}{\mathrm{Ptvb}}
$$

Note:

SL : Land supply (ha).

Pi : Actual production for each commodity (its unit depends on type of commodity). Calculated commodity includes agriculture, plantation, forestry, husbandry, and fishery.

$\mathrm{Hi} \quad$ : Price of each commodity per unit (Rp/unit) on producer level.

$\mathrm{Hb}$ : Price of rice per unit $(\mathrm{Rp} / \mathrm{kg})$ on producer level.

Ptvb : Productivity of rice $(\mathrm{kg} / \mathrm{ha})$.

2. Land demand calculation with the following formula:

$$
\mathrm{DL}=\mathrm{N} \times \mathrm{KHLL}(2)
$$

Where: DL : Total of land demandequals to rice (ha)

$\mathrm{N} \quad$ : Population (person/people)

KHLL : Land area that is needed for welllived per individual [5]

Land area that is needed for well-lived per individual (KHLL) is a demand of welfare life for every individual divided by local rice productivity. The demand of welfare life is as worth as 1 ton of rice per capita per year. Data from national rice productivity on average, which is $2400 \mathrm{kgs} / \mathrm{ha} /$ year can be used

For some regions that have no data about local rice productivity

\begin{tabular}{|c|c|c|c|c|c|}
\hline No & Sub-district & $\begin{array}{c}\text { Population in } \\
2001\end{array}$ & $\begin{array}{c}\text { Population in } \\
2010\end{array}$ & $\begin{array}{c}\text { Population in } \\
2015\end{array}$ & $\begin{array}{c}\text { Population in } \\
2001-2015\end{array}$ \\
\hline 1. & Mijen & 38.843 & 48.923 & 69.382 & 78,6 \\
\hline 2. & Gunungpati & 58.130 & 65.465 & 91.075 & 56,7 \\
\hline 3. & Banyumanik & 106.834 & 121.855 & 147.449 & 38,0 \\
\hline 4. & Gajahmungkur & 58.482 & 61.668 & 66.499 & 13,7 \\
\hline 5. & Semarang Selatan & 84.103 & 85.591 & 84.496 & 0,5 \\
\hline 6. & Semarang Utara & 122.929 & 126.765 & 143.469 & 16,7 \\
\hline 7. & Semarang Tengah & 106.090 & 74.228 & 69.896 & $-34,1$ \\
\hline 8. & Semarang Barat & 148.753 & 159.425 & 176.575 & 18,7 \\
\hline 9. & Semarang Timur & 84.044 & 81.747 & 82.542 & $-1,8$ \\
\hline 10. & Candisari & 78.336 & 77.937 & 89.983 & 14,9 \\
\hline 11. & Tembalang & 106.090 & 127.008 & 177.333 & 67,2 \\
\hline 12. & Pedurungan & 141.695 & 163.562 & 200.726 & 41,7 \\
\hline 13. & Genuk & 63.904 & 80.600 & 108.252 & 69,4 \\
\hline 14. & Gayam sari & 64.104 & 70.782 & 78.395 & 22,3 \\
\hline 15. & Tugu & 24.400 & 26.976 & 34.622 & 41,9 \\
\hline \multirow[t]{2}{*}{16.} & Ngalian & 92.548 & 109.108 & 140.676 & 52,0 \\
\hline & Total & 1.350 .005 & 1.481 .640 & 1.763 .370 & 30,6 \\
\hline
\end{tabular}

Table 1. Population in Semarang in $2001-2015$

Source: Statistics Central Bureau (BPS) of Semarang city in 2016 [6] 


\section{Determination of land capacity status}

Land capacity status is obtained from the ratio between land supply (SL) and land demand (DL). If SL > DL, it means surplus land capacity, but on the contrary, if SL < DL means deficit land capacity.

\section{Discussions}

The population growth will increase resource consumption, not only in quantity but also in quality. This causes the decrease of carrying capacity, for sure. Something noticeable from the table above is that outskirts of the city like Mijen, Gunungpati, Genuk, Tembalang, and Ngaliyan Sub-districts have high population growth. While subdistrics in the downtown like Semarang Tengah (Central Semarang) and Semarang Timur (East Semarang) have lower population, due to some big projects that have taken over the settlements. The growing population in the outskirts is because of urbanization, or urban people who just want to have a comfortable place to live.

\subsection{Land capacity formula}

Land capacity can be determined by capacity, and it is calculated based on land function area divided by population. So, the concept of land capacity formula is on the contrary to population density concept.

The formula is:

\section{$\mathbf{A}=\mathbf{L} / \mathbf{P}$}

Where, $\mathrm{A}=$ Land capacity

$\mathrm{L}=$ Land area (ha)

$\mathrm{P}=$ Population.
Land consumption depends on population of the city. The more population in a city, the land consumption per capita will be smaller. Look at the following table.

Table 2. Land Consumption per Capita

\begin{tabular}{|c|c|c|}
\hline No & $\begin{array}{c}\text { Population } \\
\text { (person) }\end{array}$ & $\begin{array}{c}\text { Land Consumption } \\
\text { per Capita (ha/capita) }\end{array}$ \\
\hline 1 & 10.000 & 0,100 \\
\hline 2 & 25.000 & 0,091 \\
\hline 3 & 50.000 & 0,086 \\
\hline 4 & 100.000 & 0,076 \\
\hline 5 & 250.000 & 0,070 \\
\hline 6 & 500.000 & 0,066 \\
\hline 7 & 1.000 .000 & 0,061 \\
\hline 8 & 2.000 .000 & 0,057 \\
\hline
\end{tabular}

Based on data of Semarang city population, the most populous sub-district is Pedurungan with the population of 200,726 persons, therefore the land consumption is as follows:

Population 250,000 - 100,000, land consumption $0.076-0.070$

$$
\begin{aligned}
& 150,000=0.06 \\
& 25,000=0.01
\end{aligned}
$$

If the population in Pedurungan 200,726 people, it is between 100,000 and 250,000.

Yeates scale limit $=((200,726-100,000) \times 0.01)-$ $0.076=0.072$.

With the same way, the Yeates scale limit can be applied for all sub-districts.

Table.3 Carrying Capacity in Semarang City

\begin{tabular}{|l|l|l|l|l|l|l|}
\hline $\begin{array}{l}\text { No } \\
(\mathbf{1})\end{array}$ & Sub-district (2) & $\begin{array}{l}\text { Population } \\
\mathbf{( 3 )}\end{array}$ & $\begin{array}{l}\text { Land area } \\
\mathbf{( h a )} \\
\mathbf{( 4 )}\end{array}$ & $\begin{array}{l}\text { Carrying } \\
\text { capacity } \\
\mathbf{( 5 )}=\mathbf{( 4 ) / ( 3 )}\end{array}$ & $\begin{array}{l}\text { Yeates } \\
\text { scale limit } \\
\mathbf{( 6 )}\end{array}$ & $\begin{array}{l}\text { Carrying } \\
\text { Capacity Status } \\
\mathbf{( 7 ) = ( 5 ) - ( 6 )}\end{array}$ \\
\hline 1 & Mijen & 69.382 & 5.755 & 0,083 & 0,087 & Threshold \\
\hline 2 & Gunungpati & 91.075 & 5.411 & 0,059 & 0,082 & Overshot \\
\hline 3 & Banyumanik & 147.449 & 2.569 & 0,017 & 0,073 & Overshot \\
\hline 4 & Gajahmungkur & 66.499 & 907 & 0,014 & 0,084 & Overshot \\
\hline 5 & Semarang Selatan & 84.496 & 593 & 0,007 & 0,081 & Overshot \\
\hline 6 & Semarang Utara & 143.469 & 1.097 & 0,008 & 0,075 & Overshot \\
\hline 7 & Semarang Tengah & 69.896 & 605 & 0,008 & 0,081 & Overshot \\
\hline 8 & Semarang Barat & 176.575 & 2.174 & 0,012 & 0,074 & Overshot \\
\hline 9 & Semarang Timur & 82.542 & 770 & 0,009 & 0,080 & Overshot \\
\hline 10 & Candisari & 89.983 & 654 & 0,007 & 0,079 & Overshot \\
\hline 11 & tembalang & 177.333 & 4.420 & 0,024 & 0,074 & Overshot \\
\hline 12 & Pedurungan & 200.726 & 2.072 & 0,010 & 0,072 & Overshot \\
\hline 13 & Genuk & 108.252 & 2.739 & 0,025 & 0,079 & Overshot \\
\hline 14 & Gayamsari & 78.395 & 618 & 0,008 & 0,081 & Overshot \\
\hline 15 & Tugu & 34.622 & 3.178 & 0,117 & 0,090 & Quite safe \\
\hline 16 & Ngaliyan & 140.676 & 3.799 & 0,035 & 0,077 & Overshot \\
\hline & SEMARANG & $\mathbf{1 . 7 6 3 . 3 7 0}$ & 37.370 & 0,021 & 0,063 & Overshot \\
\hline
\end{tabular}

Source: Data from Analysis Statistics 
Based on yeates scale, the carrying capacity status of 14 sub-districts out of 16 sub-districts $(87.5 \%)$ is overshot. The other two are quite safe (Tugu) and threshold (Mijen). The highest range of carrying capacity is Tugu (0.117) and the lowest is Candisari (0.007). Mijen and Tugu are predicted to be overshot in the near future due to high population growth in the outskirt areas.

\subsection{Conclusion and suggestion}

Rapid population growth in Semarang city tends to happen in the outskirt areas such as Mijen, Gunungpati, Genuk, Tembalang, and Ngaliyan. This indicates that outskirt areas are more attractive than downtown areas, especially for immigrants, even downtown dwellers have moved to outskirt areas.

Among 16 sub-districts in Semarang, only Tugu sub-district is quite safe and Mijen sub-district is in threshold. It indicates that $87.5 \%$ areas in Semarang city has overshot carrying capacity, especially downtown areas like Candisari and South Semarang sub-districts.
The government of Semarang city should control population growth by restricting Building Permit (IMB) or controlling farm land conversion.

\section{References}

1. Rahardjo, Mugi. Pengantar Ekonomi Sumber daya alam. UNS Press, Surakarta. 1997.

2. Kusumawati, Agni. Rantai Nilai (Value Chain) Agribisnis Labu Di Kecamatan Getasan Kabupaten Semarang. Skripsi. Fakultas Ekonomika Dan Bisnis Universitas Diponegoro Semarang. Semarang. 2013.

3. Hadi. Sudharto, P. Bunga Rampai Manajemen Lingkungan. Dua Satria Offset. Yogyakarta, (2014)

4. Muta'ali, Lutfi. Daya Dukung Lingkungan untuk Perenanaan Pembangunan, Badan Penerbit Fakultas Geografi UGM, Yogyakarta, (2012)

5. Soemarwoto. Ekologi, Lingkungan Hidup dan Pembangunan. Yogyakarta : Djambatani.1983. 